\title{
Leases as Inhibitors of Best Practice in Service Charge Management
}

\begin{tabular}{|r|l|}
\hline Journal: & Property Management \\
\hline Manuscript ID & PM-07-2018-0041.R1 \\
\hline Manuscript Type: & Research Paper \\
\hline Keywords: & best practice, property lease, service charge, accounting \\
\hline \multicolumn{2}{|}{} \\
\hline
\end{tabular}

SCHOLARONE"

Manuscripts 


\title{
Leases as Inhibitors of Best Practice in Service Charge Management
}

\author{
Key Words \\ best practice, property lease, service charge, accounting
}

\section{Introduction}

The following paper considers UK commercial leases and their role in generating occupational best practice. Given that the lease is a contract by which one party conveys property to another for a specified time in return for a periodic payment, it is evident that the legal terms of the lease are paramount in all dealings associated with the arrangement. Since there is also well established case law and legal form to these contracts, then it can be taken that they offer the 'best' arrangement for both parties in what is an expensive and, potentially, long-lasting relationship. Unfortunately, these arrangements can be quite conservative in their response to change, and, for understandable reasons, fail to foresee changes in the future requirements of both parties. Yet, as legal obligations on both parties, the provisions of leases must be honoured, even where they generate inefficiency or limit improvement.

Within the working relationship of landlords and tenants, the terms of the lease are self-evidently inviolate. However, where they fail to clearly prescribe rights and obligations when faced with new paradigms due to their fixture in a time and a place, then interpretation and reinterpretation can lead to conflicts on how to deal with 'the new'. At the broader level, sectoral change and the generation of best practice can also fall foul of the stated requirements of the lease since it may take decades for older leases to lapse. Despite good intentions, the lease is always predominant.

The following paper examines the role of leases in enabling and discouraging the search for generating agreement on minimum best practice expectations within the management and financial reporting practices of service charges. This is a field that is subject to a code of practice, soon to be a practice statement, issued by the Royal Institution of Chartered Surveyors (RICS), but one where existing leases might have 
been drawn up over two decades ago, and where provisions of the underlying lease may conflict with, or be silent on, the Code's requirements on the management, accounting, certification and auditing requirements for the service charge process.

The key argument developed here is that urgent attention is needed to the drawing up of leases so that modern commercial leases incorporate Code-compliant provisions that facilitate the adoption and dissemination of best practice. Currently, relatively little is known about the degree to which an average UK commercial lease complies with the Code's requirements for accountability and management transparency, or whether these legal documents provide adequate prescriptive guidance in these key areas. The research reviews the provisions within leases at 90 UK multi-let commercial office buildings and assesses the quality and transparency of provisions within current commercial leases. From this it identifies whether provisions exist that support the requirements and objectives of the RICS Code.

The paper is set out in the following order. A short literature review defines the subject under consideration. This is quite limited due to the narrow focus of the paper. Next, the paper establishes its method and methodology. It then presents its data together with descriptive analysis. Finally, it offers a conclusion.

\section{Literature review}

UK commercial service charges have, in the last few years, been the subject of increased professional scrutiny after many years of being seen as problematic, yet unimportant (see, for example, Calvert 2008, Eccles and Holt 2009, Eccles, Holt and Zatolokina 2011 and Holt 2015). There has also been international discussion on the issue as well (see, for example, Halvitigala 2018). The result is a number of editions of a voluntary code of practice drawn up by RICS and a number of trade bodies. Despite some calls to be so (for example, Eccles and Holt 2009) service charges are not subject to statutory legislation, and the only mandatory guidance on the requirements related to their management are those stipulated in individual lease agreements. This is why it is such an important document in establishing patterns of occupational behaviour. 
A service charge is only payable if the lease specially requires it, and each individual lease agreement may or may not contain specific lease provisions that describe the financial reporting, management, administrative, and audit processes that apply when managing the service charge process. The purpose of the service charge is to cover payments for the maintenance and upkeep of common areas in multi-let buildings. These may include contribution to a sinking fund. Where an individual lease is silent in terms of these requirements, the main practical guidance for the facilities manager or managing agent comes from the non-mandatory RICS Code of Practice, Service Charges in Commercial Property, which came into force in 2007 (RICS, 2014). A not unreasonable expectation is that lease writers will take into account this clear statement of best practice, and include it into the lease. It might also be assumed that occupiers would require the inclusion of such in order to guarantee minimum service levels and provide them with an enforceable and clear service level.

This paper is written at a time when a revised RICS commercial Code is currently under development and should be published during 2018. If one considers both the official and unofficial versions, this will be the sixth edition of the Code, following those published in 1996, 2000, 2006, 2011, 2014 (RICS, n.d.; Guide to Guide to Good Practice Working Party, 2000, RICS, 2006, 2011, 2014). This has also been reinforced by guidance from private companies that offer services to advise tenants, and widely disseminate practice notes on what should, and should not, be included in leases (see, for example, CBRE 2004). While the Code and its requirements have negotiated, confirmed and laid out what is best practice, research indicates that overall levels of compliance with its guidance remain poor, in both the UK commercial office and retail sectors (see, for example, Property Solutions, 2017, and Holt, Paul and White, 2017). There certainly appears to be an 'expectations gap' between what this occupational wisdom sets out as the service that commercial tenants might expect to receive in terms of the service charge accounting and administrative process, and what managing parties are actually providing (Holt, 2015). Questions concerning the reluctance of tenants to demand such compliance before signing a lease remain an area for further research since they appear inexplicable when examined rationally. The existing literature provides a multitude of reasons for landlord disinterest, but the most persuasive remains the lack of 
mandatory enforcement on RICS members and the lack of any statutory mandate. The Code remains a non-mandatory guidance note for its members. Despite this, the RICS is clear about the professional importance in following the Code's requirements: "A practitioner conforming to the practices recommended in this Code is unlikely to be adjudged negligent on account of having followed these practices" (RICS, 2014, p. 2).

RICS clearly expects that practitioner-members should only depart from the practice recommended in the Code where there is good reason to do so, such as when it conflicts with existing lease terms. The Code cannot override the lease, but "if read in conjunction with it, it can enable users to identify the best way forward in interpreting that lease to ensure effective management of services" (RICS, 2014, p. 7). The Code is also endorsed by many commercial institutions, such as the British Council of Offices, British Council of Shopping Centres, British Property Forum, CoreNet and the British Retail Consortium. This really should ensure the engagement of their many landlord members.

In a similar vein, the lease offers the best chance for an occupier to firmly establish what they can, and can not, be expected to pay as part of their service charge. This makes it an ideal point for them to negotiate clear agreement on service charge management. "If the wording of the service charge clause allows an item, then the occupier must pay whether or not it is a repair and maintenance item or a service, or whether the item in question is in fact an improvement. Thus it is imperative that at the contract negotiation stage the occupier seeks to exclude such wording which may allow items of capital expenditure within the service charge. This is usually the only time a potential occupier can seek to control the inclusion of costs within the service charge" (CBRE 2004, no page). Therefore, there are two separate forces acting on lease writers that ought to ensure good lease writing: agreed best practice, and tenant negotiation of their interest.

Given this pre-eminence of the lease, it is evident that the clarity of existing commercial lease provisions, and the extent to which they incorporate the Code's recommendations, each plays a critical role in supporting/ opposing the adoption of what is agreed as best practice within commercial service charges. The Code even 
acknowledges the need for leases to incorporate revised service charge provisions that comply with the principles and provisions of this Code, and The City of London Law Society and Practical Law Company have both drawn up such documents for use by practitioners. In addition, the British Property Federation (BPF, 2017) commissioned the Modern Commercial Lease (MCL) template, which incorporates many of the RICS Code's accounting and reporting requirements. This reinforces the engagement of landlord bodies with the Code.

Despite this critical role in developing best practice, little is currently known about the extent to which current lease terms either conflict with or support the Code's requirements. In earlier research, Holt (2015) reviewed 20 leases at UK multi-let office buildings larger than $50,000 \mathrm{sq}$. $\mathrm{ft}$, and found that none included a requirement for an audit or independent accountants' report, or specified whether accounts should be prepared on a cash or accruals basis. In addition, only $50 \%$ of the leases included a provision that entitled the occupier to inspect the service charge records or vouchers. While it is hard to generalise from such a small study, this pilot exercise indicated the need for further lease-based research, as lease deficiencies appeared to exist that might prevent the adoption of the Code's best practice requirements.

This current study provides the first large scale investigation of the extent to which commercial leases support the best practice recommendations of the RICS Code. Given the nature of its data, the paper focuses only on practice within the UK. Leases in general, and service charges in particular, are not easily generalised up into a universal framework because of their emplacement within a particular legal jurisdiction.

\section{Methodology}

Provisions within leases at 90 UK multi-let commercial office buildings were reviewed in this study. The sample was taken as a random representative selection from a population of 112 leases. This population was derived from the clientele of one property management consultancy company, Property Solutions UK, Bristol. A core problem of researching this issue is the confidentiality of the legal agreements made by landlords with tenants, and the lack of interest in making confidential details available to third party researchers. The research is, therefore, both dependent 
upon, and grateful to, Property Solutions for their involvement. Of course, the result is that the population, and resultant sampling, are not of all UK leases but of this company's clients. Still, whilst the source of the documents may indicate a potentially biased dataset, the 90 leases were prepared by 67 different legal firms for 86 different landlords and 37 tenants. Further, because the company is employed to actively manage the properties, any skewing of results is likely to be to the positive. One would expect actively managed tenancies to produce improved performance and more rigorous policing of what is a non-mandatory Code. Therefore, what is presented here can be taken as the 'best case' measurement of the industry's performance.

Given the nature of these data, what follows utilises descriptive statistics only. The paper sets out to test a general principle, that of whether leases engage with best practice as determined by the multiple authors of the code of practice. Whilst further statistical analysis might offer additional insight, the focus of this paper is best served by this simpler methodological approach.

82 of the leases had an inception date after the publication of the $2^{\text {nd }}$ unofficial version of the RICS Code in 2000, and 62 were signed after the release of the first official version of the Code in 2006. As a result, the sample includes a variety of inception dates, with most documents applicable for assessing whether "modern leases" incorporate and/or support the best practice recommendation in some version of the RICS Code. The average and median length of each lease were 72.5 and 63 pages, respectively. Table 1 provides a summary of the lease length within the sample; it is clear that 'shorter' lease lengths are now normal practice confirming a shift away from what used to be considered the 25 year 'normal' length (see, for example, Halvitigala et al 2011 for a useful overview on this - albeit with a New Zealand perspective).

\begin{tabular}{|l|r|r|}
\hline \multicolumn{3}{|l|}{ Table 1: Lease duration } \\
\hline Lease term & No. & $\%$ \\
\hline 5 or less & 18 & $20.0 \%$ \\
\hline
\end{tabular}




\begin{tabular}{|l|r|r|}
\hline $6-10$ & 34 & $37.8 \%$ \\
\hline $11-15$ & 23 & $25.6 \%$ \\
\hline $16-20$ & 9 & $10.0 \%$ \\
\hline $21-24$ & 1 & $1.1 \%$ \\
\hline 25 or more & 5 & $5.6 \%$ \\
\hline Total & 90 & $100.0 \%$ \\
\hline
\end{tabular}

In total, the 90 leases included 2,076,008 sq. ft. and $£ 78,562,042$ of floor space and annual service charge expenditure, respectively. The average and median service charge expenditures for the 90 leased buildings were $£ 913,512$ and $£ 520,489$, respectively. Table 2 illustrates the range in annual service charge expenditure for each lease, and highlights that $22.2 \%$ of the sample represented commercial buildings whose annual service charge expenditure exceeded $£ 1,000,000$ per annum.

\begin{tabular}{|l|r|r|}
\hline Table 2: Annual service charge expenditure \\
\hline Annual service charge & No. & $\%$ \\
\hline$£ 50,000$ or less & 5 & $5.6 \%$ \\
\hline$£ 50,001-£ 250,000$ & 20 & $22.2 \%$ \\
\hline$£ 250,001-£ 500,000$ & 16 & $17.8 \%$ \\
\hline$£ 500,001-£ 1,000,000$ & 25 & $27.8 \%$ \\
\hline$£ 1,000,001-£ 2 m$ & 12 & $13.3 \%$ \\
\hline More than $£ 2 m$ & 8 & $8.9 \%$ \\
\hline No data available & 4 & $4.4 \%$ \\
\hline Total & 90 & $100.0 \%$ \\
\hline
\end{tabular}

The size of these sums illustrates just as how important an issue this is: service charges are often considerable amounts. Hence, whilst they remain not subject to statutory regulation in terms of their annual accounting and financial reporting, occupiers quite clearly face potential risk and liability where the commercial lease fails to provide adequate accounting provisions. Whilst puzzling in itself, it is indefensible when compared with the regulation that is obligated upon accounting mechanisms for UK residential service charges. Even small UK limited liability entities with turnovers of less than $£ 1 \mathrm{~m}$ face mandatory annual reporting requirements (for more details see Holt, 2015, and Companies House, 2016). 
Content analysis was used to analyse each lease. While this type of research method is orientated towards a positivist approach, the processing and classification of the lease data often required some degree of subjective interpretation by the researchers. As a result, the research method used to analyse the data was a hybrid mixture of quantitative and qualitative approaches. The use of hybrid methodologies is problematic because of the different epistemological and ontological assumptions within each approach but is increasingly accepted as being appropriate for applied accounting and management research (Collis and Hussey, 2009). Additionally, the issue of inter-rater reliability was considered. Again, in practice, the potential for bias in this type of work is remote as it requires limited interpretation by the researcher. The data codification required is primarily binary in nature and unproblematic where there is sufficient explanation within the lease. Judging the efficacy of a lease provision might be contentious in theory, but, in practice, the nature of the service charge renders the analysis relatively obvious. Hence, much of the data could be utilised directly. However, given the poor clarity of explanation within many commercial service charge leases, the difficulty of subjective interpretation is not to be underestimated. Whilst the quantitative data within this paper does rely on certain qualitative judgements, the resulting data are inherently sound and offer a valid examination of current lease provisions.

The data sample was used to assess the quality and transparency of certain provisions within UK commercial leases, and identified whether they supported the requirements of the RICS Code. The analysis focused on 15 critical areas within the service charge process, including whether the lease:

- Referred to the RICS Code

- Explained the landlord's covenant to provide services

- Defined what the service charge was and what costs it included

- Explained whether the service charge was collected in advance

- Included a dispute resolution provision

- Included a break clause

- Mentioned environmental sustainability

- Provided a clear and transparent accounting process, including direction about: 
- The accounting basis used (i.e. accruals or cash accounting)

- The cost apportionment methodology

- The budgetary process

- The annual cost certification process

- The time period for certification

- The "audit" or independent review process

- The tenant's ability to review the annual certificate and the accounting documents

- The time period for questioning the certificate

For each of the 15 areas under investigation, the researchers read the lease and determined whether it supplied adequate direction and clarity on the issue. By this process, each lease was assigned a binary score of 1 or 0 in each area depending on whether it provided full or inadequate direction or clarity on the matter. Once this was complete, each lease was assigned a rating out of 15 for overall compliance and support with the RICS Code. In addition to these fifteen core areas, additional analysis was conducted in other areas, such as whether the service charge was defined as rent and a service charge cap applied.

\section{Results}

\section{General results and issues}

The 90 lease documents varied widely in terms of their layout, detail and prescription. On the one hand, this was perhaps unsurprising as they were drawn up by 67 different legal firms for 86 different landlords. At the same time, the researchers expected a certain level of standardisation amongst the legal profession as to the 'norm' of lease writing. Model commercial leases exist and are promulgated by professional and trade associations. Additionally, the national and international origin of both tenants and landlords would imply some level of standardisation.

While the median lease length was 63 pages, Table 3 illustrates that 29 leases had a page count of 50 pages or less, leaving little space for detailed service charge provisions in certain areas.

\section{Table 3: Lease length}

\begin{tabular}{|l|l|}
\hline Page count & Number \\
\hline
\end{tabular}




\begin{tabular}{|l|r|}
\hline 50 or less & 29 \\
\hline 51 to 100 & 49 \\
\hline 101 to 150 & 6 \\
\hline $151-200$ & 4 \\
\hline 201 or more & 2 \\
\hline Total & 90 \\
\hline
\end{tabular}

Most of the lease documents were complex to read and difficult to navigate, especially when it came to finding specific direction for certain service charge-related issues. There was certainly no attempt at any form of 'plain English' or guidance to their complexity and this would certainly appear to act against non-experts and SMEs. While many leases completely lacked direction in some areas, others needed some interpretation and re-reading to assess the exact meaning of certain provisions. This is a critical observation, as a lack of transparency may lead to an enhanced risk of disputes and disagreements between the contracted parties. This also reinforces arguments by RICS that tenants need professional advice (from chartered surveyors, of course) prior to agreeing to a lease.

In terms of the 15 core metrics analysed by the research, results were mixed. Table 4 presents the overall results of the study, which indicate that most leases failed to include provisions to support many of the best practice requirements of the RICS Code. For example, a higher number of leases included detailed provisions about environmental issues (34\%) than those that specifically mentioning the importance of complying with the RICS Code (13\%).

\begin{tabular}{|l|c|c|}
\hline \multicolumn{2}{|l|}{ Table 4: Analysis of provisions within the 90 leases } & \\
\hline Lease provision content & $\begin{array}{c}\text { No. with } \\
\text { clear } \\
\text { provisions }\end{array}$ & $\%$ \\
\hline Mention of RICS Code (83 leases relevant) & 11 & $13 \%$ \\
\hline Landlord's covenant to provide services & 84 & $93 \%$ \\
\hline Apportionment methodology given & 87 & $97 \%$ \\
\hline Service charge collected in advance & 84 & $93 \%$ \\
\hline Provisions for dispute resolution & 38 & $42 \%$ \\
\hline Mention of environmental issues & 31 & $34 \%$ \\
\hline Service charge defined & 81 & $90 \%$ \\
\hline Accounting basis given & 0 & $0 \%$ \\
\hline Service Charge budget required & 38 & $42 \%$ \\
\hline
\end{tabular}




\begin{tabular}{|l|l|l|}
\hline Annual cost certification process explained & 85 & $94 \%$ \\
\hline Time Period for certification & 19 & $21 \%$ \\
\hline "Audit" requirements defined & 37 & $41 \%$ \\
\hline Tenant's ability to question certificate & 44 & $49 \%$ \\
\hline Time Period for questioning certificate & 25 & $28 \%$ \\
\hline Break Clause & 29 & $32 \%$ \\
\hline
\end{tabular}

Since only $11 \%$ of leases signed after the inception of the Code directly referred to it, it is clear that landlords are not promoting their convergence with the Code and that tenants are still signing agreements anyway. One clear conclusion for this paper is that the industry should include lease provisions that protect both parties by incorporating direct reference to the role of the professional guidelines of the professional and trade associations of which they are - presumably - members. One national tenant and one major landlord are represented on the working panel, so there seems no rationale for this not to happen.

While Table 4 identifies a number of weaknesses in the overall level of transparency and detail within commercial leases, it does not reveal the extent to which each individual lease fails to provide the information and guidance necessary for managing the service charge arrangement. Figure 1 ranks the 90 leases by the extent to which they supplied relevant information for each of the 15 metrics highlighted in Table 4 . Only $77.8 \%$ of the leases provided direction or transparent guidance in 7 or more of the 15 analysed areas, with $22.8 \%$ providing relevant and adequate guidance in 6 or less areas. While some of the 15 metrics, such as supplying information about break clauses, may not be relevant for every lease agreement, best practice expects modern leases to supply clear information about the service charge process. 
Figure 1: Lease transparency in 15 key areas relevant to the RICS Code

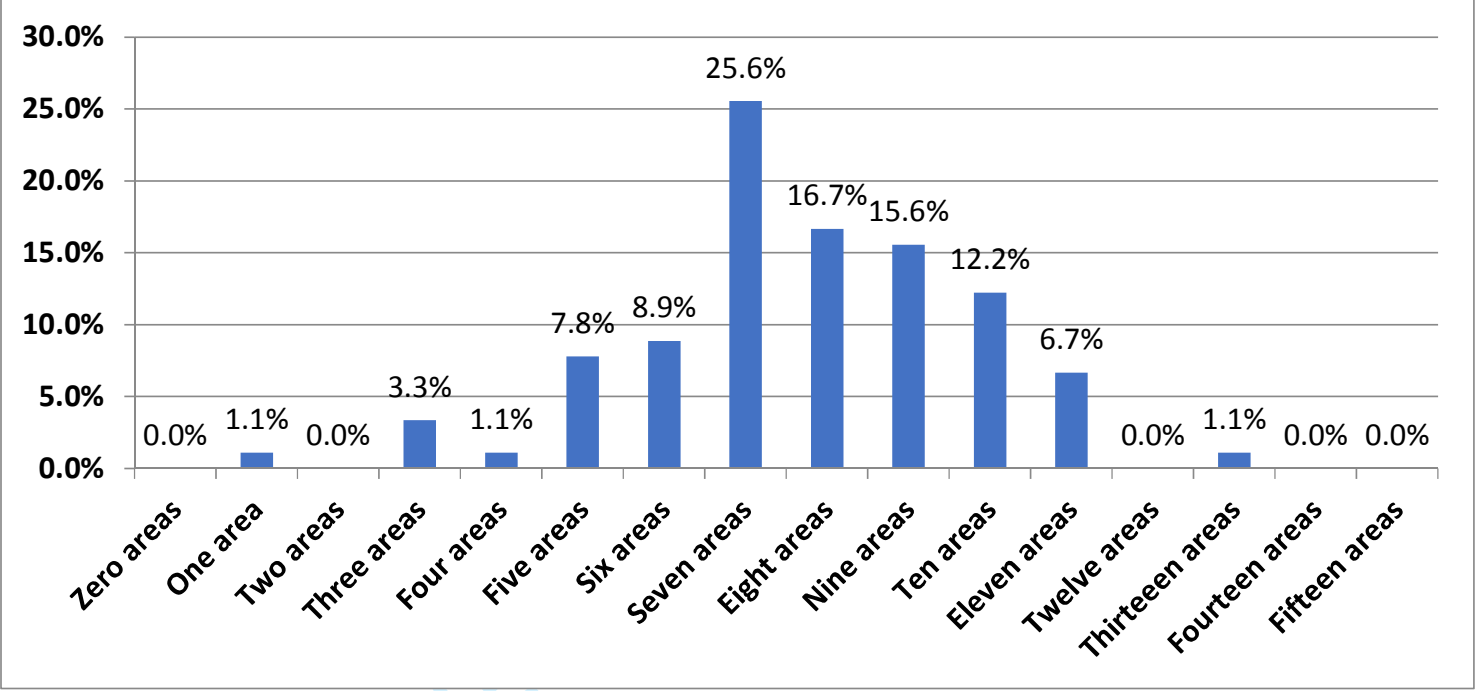

The results for the individual leases identify fundamental problems in current lease transparency and direction, and provide further descriptive evidence of the patchy compliance with the RICS Code. As the lease establishes the contractual rights, obligations and duties of each party, it should be clearly written, complete and built upon principles accepted by occupational experts as best-practice. This, then, raises the question of what was accepted as best practice at the time of signing. As the sample incorporated documents with an array of lease inception dates, analysis was also conducted as to whether the signing year influenced the level of lease transparency in terms of the fifteen metrics. The results of this inception year analysis are shown in Figure 2, and illustrate the variety of the results across years. While the trend indicates a small increase in recent years, overall transparency levels are still relatively poor. Therefore, there is no correlation between lease clarity, specific code requirements or time for dissemination of ideas into the profession. In short, leases created after an edition of the code of practice was published and disseminated are showing no significant signs of improvement. 


\section{Accounting-related issues}

The research looked specifically at whether current lease provisions support the Code's accounting and audit guidance because this is an area that has seen significant improvement in guidance. Since its inception, the Code has attempted to improve both the relevance and reliability of the service charge accounting process, and now includes detailed requirements for the preparation, dissemination and review of the service charge accounts (see Holt, 2015 and Holt, White and Paul, 2017). In order to assess whether current leases support the Code's attempts at improving the service charge accounting process, each lease's provisions were reviewed to see whether they provided information relevant to the following ten accounting-related metrics:

- Definition of the service charge and what costs its includes

- Explanation of whether the service charge was collected in advance

- The accounting basis used (i.e. accruals or cash accounting)

- The cost apportionment methodology

- The budgetary process

- The annual cost certification process

- The time period for certification 
- The "audit" or independent review process

- The tenant's ability to review the certificate and accounting documents

- The time period for questioning the certificate

Figure 3 presents the results of this accounting-related lease analysis. Most obvious here is that only $30 \%$ of leases provided the necessary information in 7 or more of these key accounting aspects. Almost a fifth failed to manage even a half.

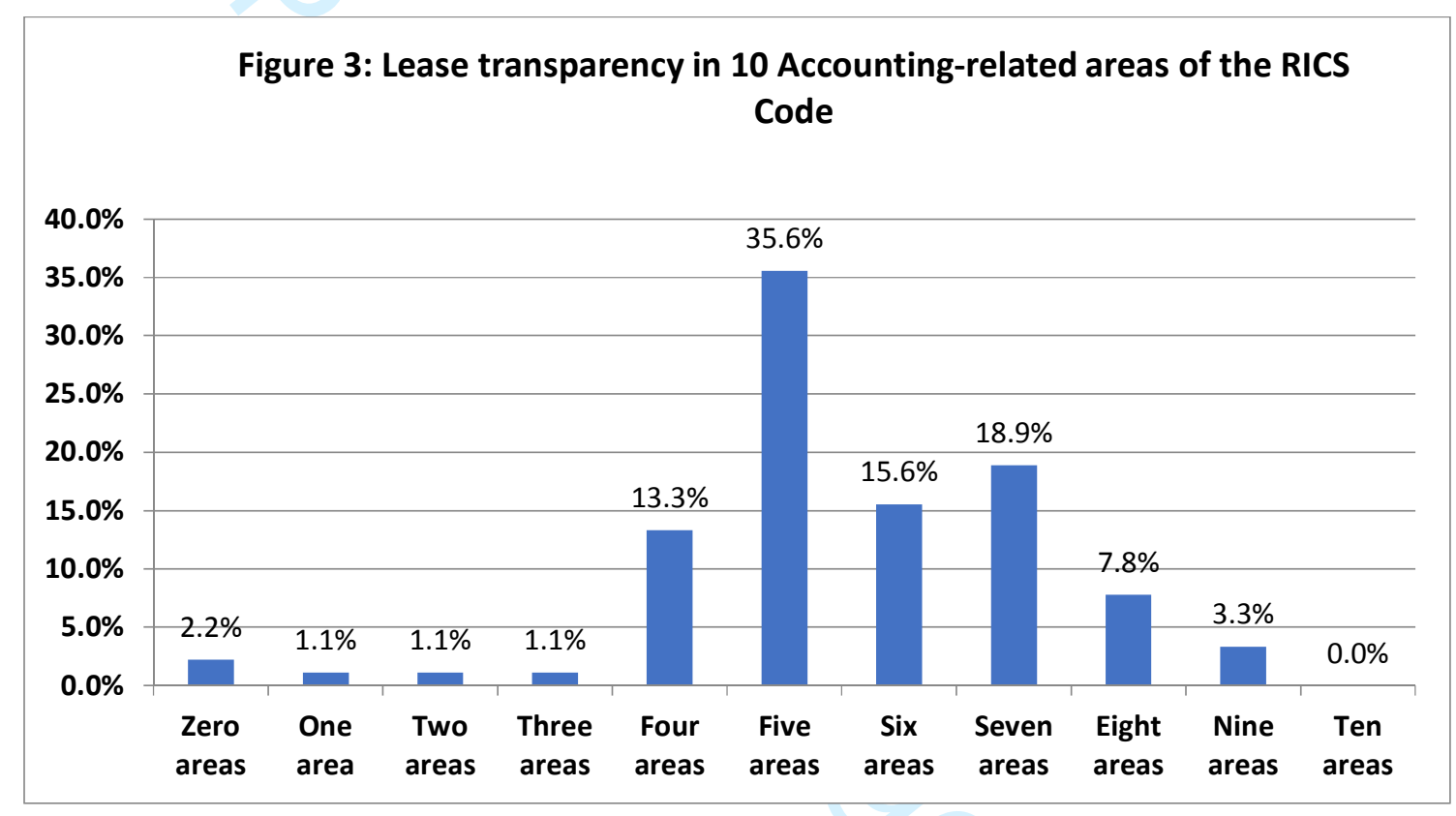

In most cases, current leases were either silent or lacked direction in areas prescribed by the Code; leases are evidently not adopting it. This raises a serious question over why such deliberate exclusion - clearly agreed as best practice - is being carried out. This concern is reinforced when considering inception date, and whether the newness of the proposals might provide some explanation (and defence). Figure 4 illustrates whether the overall level of these accounting omissions is influenced by the inception date of the lease, and the results suggest that more recent leases also fail to provide sufficient levels of accounting transparency and direction. There is little sign of any time-related improvement that might suggest that lease-writers are becoming cognizant of the Code and incorporating it. Equally, a lease is signed by a tenant and the occupier side is, therefore, exhibiting quite 
baffling disinterest in this shift in professional practice that accords them greater transparency and better service.

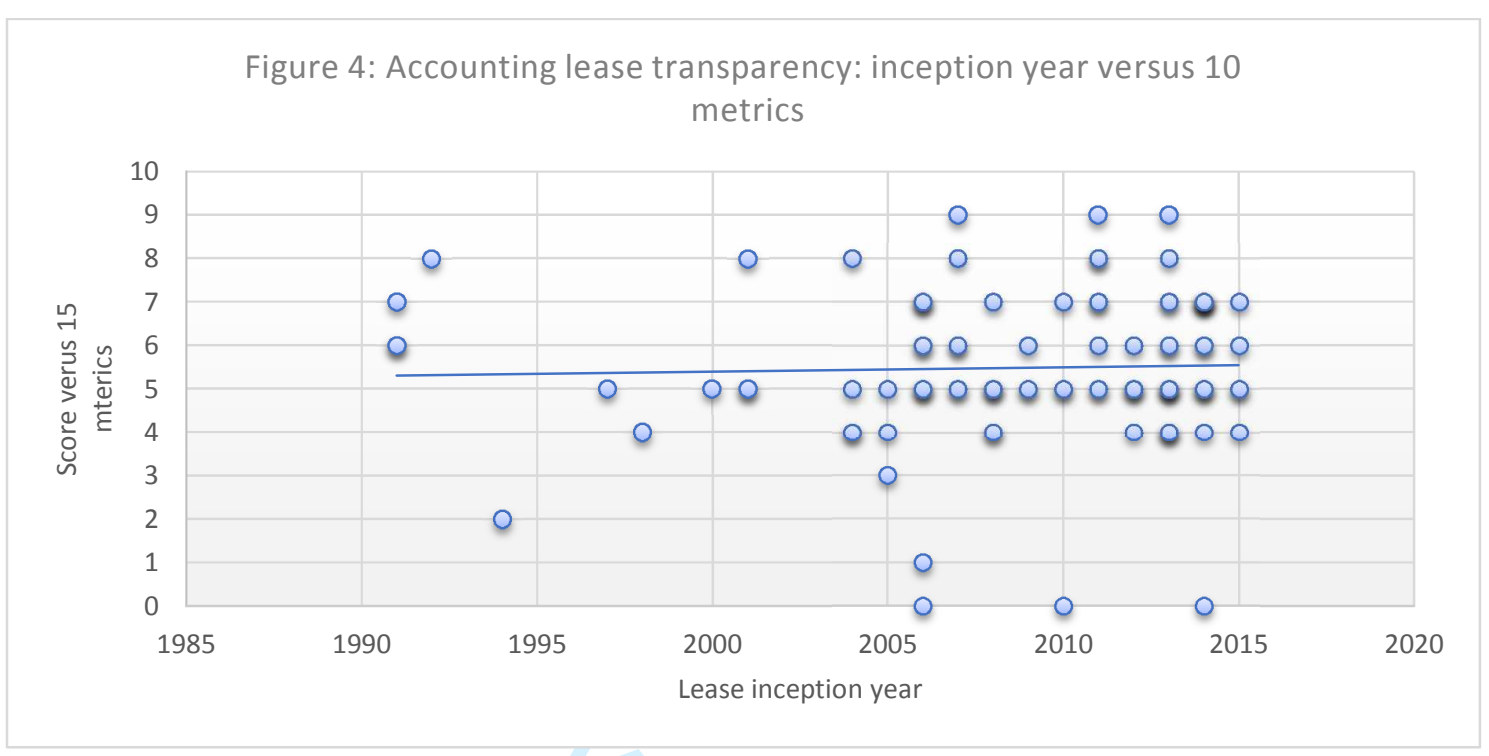

Adopting a professional accounting approach for the management of service charge costs and monies is necessary for the protection of all parties, so the failure of current leases to outline key protocols is very disappointing. For example, while Core Principle 24 of the RICS Code specifies that "managers will issue budgets to occupiers, including an explanatory commentary at least one month prior to the start of the service charge year" and "detailed statements of actual expenditure...within four months of the service charge year-end" (RICS, 2014, p. 6), most leases do not include provisions that support such ideals. In many instances, leases do not include a requirement for the preparation of an annual budget (58\% of leases), and specify differing time periods for the provision of both budgets and annual reconciliation certificates. Yet tenants are agreeing to this.

In terms of other critical accounting aspects, no lease specified the accounting basis that must be used for the preparation of the annual service charge accounts ( 0 of 90 leases). This is a critical omission, both because the RICS Code requires the annual accounts to be prepared under the accrual basis, but also because it is the only rational and transparent process to adopt. In contrast, $94 \%$ of leases specified the 
process for the annual service charge accounting and certification process, but only $21 \%$ included a time period that the certification must be completed within. Similarly, concerning the process of the audit, and whether it is independently scrutinised, only $41 \%$ of leases formally specified the "audit" or review requirements for the service charge accounts, and only $49 \%$ granted tenants with a right to inspect the service charge accounting documents. These are very serious omissions in what may be potentially large sums.

Overall, in many accounting-related areas, commercial leases provide a vacuum of direction and guidance. As a result, it is no surprise that many service charge accounting documents are inconsistent, untimely, lack detail, and offer little in the way of assurance to tenants (see Holt, 2015 for more detail on these issues). It raises a series of questions, not least as to why tenants sign such leases and why the legal profession sees the protocols, that it endorses as best practice, as unnecessary.

\section{Conclusions and recommendations}

Many of the lease analysis results are disappointing, although, they are, perhaps, hardly a surprise given the traditional occupational disinterest in service charge management. However, the findings are clearly set in an environment in which all commercial and professional parties now agree on an established benchmark of best practice. As long ago as 2004, CBRE were describing the poor performance in this area, not as 'landlord bashing', but of fair treatment for occupiers. "It is not CBRE's aim to antagonise property owners, but rather to promote a working partnership with landlords/managing agents, in progressing service charge management, whilst ensuring that operational costs are legitimately and properly recovered" (CBRE 2004, no page). Three editions of the RICS code of practice are a response to those considerations, and these have been widely consulted upon.

Most commercial leases are difficult to navigate and lack clarity regarding key areas of the service charge process. The analysis shows that most leases are not adopting the Modern Commercial Lease (MCL) template commissioned by the British Property Federation (BPF, 2017), which incorporates many of the RICS Code's core principles and requirements. Nor do they even recognise the problems that gave rise 
to that document. Instead, they perpetuate the problems. Given this complexity and ambiguity, most leases would appear to increase the risk of legal disputes between the contracted parties.

While the publication of the 2014 RICS Code, its associated 2013 RICS accounting guidance note and the ICAEW Technical Release 11/13BL, have all helped to establish a framework of "best practice" principles for the preparation of service charge accounts and their subsequent audit and review, these have yet to be implemented in most commercial leases. The paper cannot draw upon evidence to explain definitively why the legal profession, in drawing up standard leases, is refusing to engage with what are now firmly understood best practice drivers. Indeed, the omission appears completely irrational. Given the long hard road to the development of a code of practice, that, for all of its faults, is clearly driving through improvements and generating a better tenant experience, it is very difficult to understand. Even given the recent publication of some of these documents, the discussions and problems have been known about and discussed for years. Six editions of the code is one example of that. Equally, tenants continue to sign such leases. Whilst further work might address this, the conclusion herein is that this problem needs resolving. The lease is the driving force behind the service charge process and, currently, maintains a legal barrier in the development of best practice. 


\section{References}

BPF (2017) Modern Commercial lease template. Available at: http://modelcommerciallease.co.uk/leases/ (Accessed 1 August 2017).

Calvert, J. (2008) The Loughborough Report 2008. Loughborough University Enterprises: Loughborough.

CBRE (2004) Commercial Service Charges. CBRE. Available at http://portal.cbre.eu/workspace/coming soon/Commercial Service Charges 02020 4.pdf (Accessed 18 February 2018).

Companies House (2016) Changes to Accounting Standards and Regulations, 29 February. Available at: https://companieshouse.blog.gov.uk/2016/02/29/changes-toaccounting-standards-and-regulations/ (Accessed 30 June 2017).

Eccles, T., and Holt, A. (2009) Service charges within the UK office market: evidence on accounting practice, compliance and disclosure. Brentford, U.K : Antim Research.

Eccles, T., Holt, A., Zatolokina, A. (2011) Commercial service charge management: benchmarking best practice", Journal of Corporate Real Estate, Vol. 13 Issue: 4, pp.200-215.

Guide to Good Practice Working Party (2000), Service Charges in Commercial Properties - A Guide to Good Practice, 2nd ed., RICS, London.

Halvitigala, D. (2018) The effect of service charge responsibilities on tenants' leasing experience and satisfaction: A New Zealand perspective. Journal of Corporate Real Estate 20 (1): 41-55.

Halvitigala, D., Murphy, L, and Levy, D. (2011) The Impacts of Commercial Lease Structures on landlord and Tenant Leasing Behaviours and Experiences. Pacific Rim Property research Journal. Vol 17 (4): 560-583.

Holt, A. (2015) "Commercial service charge accounting and audit: a review", Facilities, Vol. 33, No. 7/8, pp. 502-527.

Holt, A., Paul, O., and White, N. (2017), "Service charge operating report (SCOR) for offices 2017, Property Solutions (UK)", Bristol. Available at:

http://www.property-solutions.co.uk/scor-offices-2017-latest-release/ (Accessed 1 August 2017).

Property Solutions (UK) (2017), Service Charge Benchmarking and Code Compliance, Bristol. Available from:

http://www.property-solutions.co.uk/research-benchmarking/service-chargebenchmarking/ (Accessed 1 August 2017).

RICS (2006), Service Charges in Commercial Property, Royal Institution of Chartered Surveyors, London. 
RICS (2009), Service Charge Residential Management Code, Royal Institution of Chartered Surveyors, London.

RICS (2011), Service Charges in Commercial Property, 2nd ed., Royal Institution of Chartered Surveyors, London.

RICS (2013), Draft of Service Charge Accounting Charges Guidance Note, 1st ed., Royal Institution of Chartered Surveyors, London.

RICS (2014), Service Charges in Commercial Property, 2nd ed., Royal Institution of Chartered Surveyors, London.

RICS (n.d.), Service Charges in Commercial Properties: A Guide to Good Practice, Royal Institution of Chartered Surveyors, London. 


\begin{tabular}{|l|r|r|}
\hline \multicolumn{2}{|l|}{ Table 1: Lease duration } & No. \\
\hline Lease term & 18 & $20.0 \%$ \\
\hline 5 or less & 34 & $37.8 \%$ \\
\hline $6-10$ & 23 & $25.6 \%$ \\
\hline $11-15$ & 9 & $10.0 \%$ \\
\hline $16-20$ & 1 & $1.1 \%$ \\
\hline $21-24$ & 5 & $5.6 \%$ \\
\hline 25 or more & 90 & $100.0 \%$ \\
\hline Total & & \\
\hline
\end{tabular}

\begin{tabular}{|l|r|r|}
\hline Table 2: Annual service charge expenditure \\
\hline Annual service charge & No. & $\%$ \\
\hline$£ 50,000$ or less & 5 & $5.6 \%$ \\
\hline$£ 50,001-£ 250,000$ & 20 & $22.2 \%$ \\
\hline$£ 250,001-£ 500,000$ & 16 & $17.8 \%$ \\
\hline$£ 500,001-£ 1,000,000$ & 25 & $27.8 \%$ \\
\hline$£ 1,000,001-£ 2 m$ & 12 & $13.3 \%$ \\
\hline More than $£ 2 m$ & 8 & $8.9 \%$ \\
\hline No data available & 4 & $4.4 \%$ \\
\hline Total & 90 & $100.0 \%$ \\
\hline
\end{tabular}

\begin{tabular}{|l|r|}
\hline \multicolumn{2}{|l|}{ Table 3: Lease length } \\
\hline Page count & Number \\
\hline 50 or less & 29 \\
\hline 51 to 100 & 49 \\
\hline 101 to 150 & 6 \\
\hline $151-200$ & 4 \\
\hline 201 or more & 2 \\
\hline Total & 90 \\
\hline
\end{tabular}


Table 4: Analysis of provisions within the 90 leases

\begin{tabular}{|l|c|c|}
\hline Lease provision content & $\begin{array}{c}\text { No. with } \\
\text { clear } \\
\text { provisions }\end{array}$ & \% \\
\hline Mention of RICS Code (83 leases relevant) & 11 & $13 \%$ \\
\hline Landlord's covenant to provide services & 84 & $93 \%$ \\
\hline Apportionment methodology given & 87 & $97 \%$ \\
\hline Service charge collected in advance & 84 & $93 \%$ \\
\hline Provisions for dispute resolution & 38 & $42 \%$ \\
\hline Mention of environmental issues & 31 & $34 \%$ \\
\hline Service charge defined & 81 & $90 \%$ \\
\hline Accounting basis given & 0 & $0 \%$ \\
\hline Service Charge budget required & 38 & $42 \%$ \\
\hline Annual cost certification process explained & 85 & $94 \%$ \\
\hline Time Period for certification & 19 & $21 \%$ \\
\hline "Audit" requirements defined & 37 & $41 \%$ \\
\hline Tenant's ability to question certificate & 44 & $49 \%$ \\
\hline Time Period for questioning certificate & 25 & $28 \%$ \\
\hline Break Clause & 29 & $32 \%$ \\
\hline
\end{tabular}

